UDC 343.156(157)

DOI https://doi.org/10.32841/2307-1745.2019.39.28

\author{
Rozhnova V. V., \\ Ph. D. of Law Sciences, Associate Professor, \\ Leading Researcher of the Institute of Post-Graduate Education \\ National Academy of Internal Affairs
}

Savytskyi D. O.,

Ph. D. of Law Sciences, Associate Professor,

Deputy Director of the Institute of Post-Graduate Education

National Academy of Internal Affairs

\title{
ON EFFECTIVE CONFIDENCE-BASED LAW ENFORCEMENT (IN TERMS OF THE CRIMINAL PROCEDURAL LEGISLATION OF UKRAINE)
}

Summary. The article analyzes certain issues of development and current state of public confidence in relations between the state and civil society in Ukraine. The modern state of law-making and law enforcement was investigated, particularly in terms of the criminal proceeding, in the light of the functional ability of the criminal process, which is based on confidence. It is established that the corruption combating system should be aimed primarily at eliminating the conditions for corruption, rather than at combating its effects, and include not only the socio-economic, political, organizational, and legal measures, but also the technologies of shaping the public awareness. Implementation of e-governance has been recognized as one of the most appropriate, effective and promising areas of domestic governance in corruption combating system and improving public confidence.

It was determined that both law and law enforcement, while closely interlinked, have objective conditions caused by the processes occurring in society at a certain stage of its development. The criterion of the relationship and mutual influence of the law and law enforcement level in the criminal proceeding is their mutual functional ability to reach their common objectives. This is what is considered an adequate response to the expectations of society from the system of criminal justice.

Currently, there is a tendency towards willingness to change the law enforcement practice for the better only by means of legislative activity, not taking into account the systemic methodological, legal and organizational problems. However, it is impossible to influence on the objective situation and processes only by rewriting laws, without a proper methodological background, as well as administrative, managerial, and organizational measures. Only such an approach can provide for a systematic, consistent and effective implementation of the declared changes in law enforcement.

Key words: public trust, effective law enforcement, functional capacity of criminal proceedings, anti-corruption system, modern tendencies of lawmaking in the field of criminal proceedings, reform of criminal procedural legislation of Ukraine.

Introduction. In the field of law enforcement, with a clearly specified form and content, the impact of confidence as an abstract, irrational category appears to be minimal at first glance, and in the matter of establishing the regulatory model of legal relationships as compared to pragmatic expediency and efficiency, it seems generally irrelevant.
Still, there is no doubt that a man is a fundamentally selfish being, and that it implements its self-interest, primarily and above all, in a rational way. However, the man also has a moral aspect making it feel an obligation to its peers, and this aspect sometimes conflicts with selfish human instincts. The most difficult ethical rules followed by a man are always formed on the basis of repetition, traditions and examples. These rules may reflect a deep "adaptive" rationality; they can serve the economically rational objectives; they can even be the result of a rational agreement reached by a limited circle of people. However, from generation to generation, they are transmitted as irrational social life skills. These skills, in turn, ensure that people's behavior will never be reduced to a pure maximization of selfish utility [1, p. 79].

Confidence characterizes the relationship between people, no matter what system of social organization they represent. Where the confidence limits are designated by abstract characteristics, "fully trust/ do no trust at all", "trust/do not trust", "rather trust than do not trust", "rather do not trust than trust", or "trust to some extent", the degree of its influence is manifested quite specifically in actions or inaction of man, "I act/abstain from action since I trust/do not trust".

The importance of maintaining the confidence of people in the state is pointed by the Constitutional Court of Ukraine, using this category as the rule of law in its judgments. In particular, in the judgment dated April 28, 2009 № 9-rp/2009, the Constitutional Court of Ukraine, indicating the inadmissibility of narrowing the content and scope of existing rights and freedoms (according to part 3 of Article 22 of the Constitution of Ukraine), which will inevitably lead to a deterioration of the person's position in society, has made a conceptual reservation to the public authorities that the failure of the state to fulfill its obligations leads to a violation of the principles of a law-governed state, undermining the principle of a person's confidence in the state (item 5, paragraph 5) [2].

Implementing the reforms declared by the state, first of all and as usual, a complete update of legislation (in particular, on the criminal procedure) is declared without the risk of limiting the rights, freedoms and legal interests of every member of the society [3, p. 21]. However, it must be noted that amendments to the laws (without their proper scientific justification and in the absence of a comprehensive approach) do not solve the existing problems, and sometimes even create the new ones. 
The current stage of development of the Ukrainian state requires an increased focus of jurisprudence on the issues of real operational capability of the law enforcement activities in general and criminal proceedings in particular. However, in the background of international law and domestic political processes of globalization and convergence of national legal systems, implementation of legal institutions in the laws of Ukraine and formation of new types of criminal justice, the priorities of which are societal values, such as respect for rights, freedoms and legitimate interests of individual people, protection and security, the need to find the most effective means to ensure the operational capability of the "personsociety - state" system in criminal procedural relationship appears with varying intensity.

The degree of development of the topic. According to Thomas Hobbes (English philosopher of the 16-17 centuries), corruption is the root from which the contempt for all laws is sprouting at all times and under any temptation [4, p. 198]. In the modern world, corruption is recognized not as a local problem, but as a transnational phenomenon affecting the society and economy of all countries, posing a threat to stability and security of societies, undermining democratic institutions and principles, ethical values and justice, and being detrimental to sustainable development and the rule of law [5].

In modern political, social, legal and psychological sciences of Ukraine, like in many other countries, corruption is classified as a major political, economic and social problem which, in the absence of systemic counteraction on the part of the state and society, is able to spread and take root in public relations and state system generally [6, p. 18].

The genesis of corruption in Ukraine, as in other countries, has its roots, development factors and peculiarities primarily determined by its historically established state and social forms, i.e. obtaining of undue advantages for commitment of legal acts and obtaining of undue advantages for commitment of illegal acts. The combination of these forms of corrupt behavior of civil servants, their actual acquisition of the meaning of one of the attributes in relations between the state and society not only leads to ineffective actions of the government in economic, political, legal, social and other socially significant processes, but also affects the formation public awareness, causes loss of faith in the fairness and credibility of the government, even upon the formal reaching of the desired result. Loss of confidence, in turn, generates stereotypes of the mutual corruption behavior, up to the idea of "status rent" justifying corruption and seen as a mechanism of "compensatory remuneration" to civil servants for their poorly paid work [7, p. 22].

We can arrive at an obvious general conclusion that the corruption combating system shall be primarily aimed at elimination of corruption causes, not at combating its effects, and include not only socio-economic, political, institutional, legal and technological measures, but also the formation of social consciousness.

The purpose of the article is establishing the role and significance of ideological mechanisms in the anti-corruption system, ensuring the functional effectiveness of enforcement in general and in the criminal process in particular.

Presenting main material. One of the areas of corruption combating system is recognizing the extreme importance of reforms, including the administrative and judicial ones [8, p. 33]. In recent years, almost all aspects of life in Ukraine were subjected to reforming. According to the authorities and some European experts, over the recent five years, Ukraine implemented more reforms than during all previous years. According to reform creators, all of them are implemented for the sake of the public good and to meet the diverse needs of society, including a fair trial. However, according to GRECO (Council of Europe Group of States against Corruption) findings contained in Reports on the Implementation of International Commitments Undertaken by Ukraine, the public confidence in the judiciary system and politicians is still low in our country [9].

A national study conducted by the Razumkov Center Sociological Service on 7-14 February 2019 in all regions of Ukraine except for Crimea and the occupied territories of Donetsk and Luhansk regions found that the citizens of Ukraine most commonly express distrust for the state apparatus (officials) ( $83 \%$ of the poll participants do not trust them) [10]. Ukrainians trust neither the government nor the courts or the newly established anti-corruption body [11]. Besides, it is noteworthy that respondents in Ukraine most do not trust even those bodies which were established according to the so-called transparent procedure and recently began their work (for example, $65 \%$ do not trust the Supreme Court and 62\% to the Anti-Corruption Court) [12]. In general, $82.5 \%$ of Ukraine's population completely or somewhat agrees with charges regarding the corruptness, political dependency and bias of Ukrainian courts [13].

Assessing the above figures in general, expressing probably different attitudes at various polls and their results, however, we can say that they confirm the general status of public confidence in the government. In this case, a high level of negative attitude and distrust are largely shaped by two factors, a negative information field and a factor of financial and political influence on public servants. The results showed that the impact of the first factor is eliminated quite effectively upon the direct contact of citizens with public institutions. The impact of the second factor can be reduced by introduction of a set of administrative, legal and economic measures. On the way to overcoming the corruption component, in our view, a special role should be assigned to information and communication technologies, as well as e-government.

As is knows, law enforcement is a special, indirect, complex form of the law, with authoritative, organizational management, and individual-specific nature, implemented by competent, specially authorized state actors, as defined in accordance with the law $[14$, p. 6]. Therefore, the law is implemented by law enforcement, but law enforcement often determines the content of the law, too. Obviously, during the development and adoption of the law, the legislator (involving the representatives of a "professional group" at the stage of the project development and discussion) places a certain content in its form in pursuit of a specific goal. However, in the process of law enforcement, the content of law may be modified, warped and sometimes distorted, which often becomes the reason to formulate a rhetorical question, what is primary - law or enforcement?

Not delving into the reasons for this situation (which, obviously, are objective-subjective), let us note that the criterion of the relationship and mutual influence level of the law and law enforcement is their mutual functional ability to ensure the performance of common tasks of the criminal proceeding stipulated by Article 2 of the Criminal Procedure Code of Ukraine, and thus to respond adequately to the expectations of society from the criminal justice system.

The process of a large-scale reform of the criminal procedural legislation of Ukraine, which was commenced in order to improve 
its effectiveness, particularly within implementation of the Judicial Reform Concept in Ukraine (1992) [15], continued within implementation of the Criminal Justice Reform Concept for Ukraine (2008) [16], and formally ended with adoption of the current Criminal Procedure Code of Ukraine [17] in April 2012, but actually lasts until today. Maybe not so extensively, but the reform of domestic criminal procedural legislation became a permanent phenomenon for modern legal system of Ukraine. It would seem that it can be assessed positively, as a necessary and timely response of the legislator to developments in the relevant public relations and objective needs of the enforcement actors in this area. However, in 2015, in the Strategy of Reforming the Judiciary System, Law-Making and Related Legal Institutions for 2015-2020, the state of justice, operation of the prosecution and criminal justice as related legal institutions is estimated as the one having its drawbacks, which are related, in particular, to the strategic planning and legislative process issues, including an excessive focus on short-term solutions in the legislative process, a lack of a systemic vision in shaping the democratization of the justice sector in the long, medium and near term [18].

The main source of the criminal procedure law, i.e. the current Criminal Procedure Code of Ukraine, is effective since November 20,2012, although the first amendments thereto were made yet on July 5, 2012, i.e. before its entry into force. Subsequently, the Criminal Procedure Code of Ukraine (sometimes along with other sources of the criminal procedural law of Ukraine) was amended every year. In general, the Criminal Procedure Code of Ukraine was amended in one or another way by more than 55 laws of Ukraine.

Some of them changed the regulation of certain procedural acts (e.g., temporary seizure of property and search [19]), or introduced new procedural mechanisms for implementation of new penal institutions (e.g. special confiscation [20]), while the others made systemic amendments to the regulatory and criminal procedural activities of some participants of the criminal proceedings or at certain stages of the process (e.g., regulation of operations of the Criminal Cassation Court of the Supreme Court as the court of cassation [21]).

Certain articles of the Criminal Procedure Code of Ukraine were amended repeatedly during six years of its validity. For example, Article 170 of the Criminal Procedure Code of Ukraine was amended six times (by the laws of Ukraine dated 18/04/2013, 23/05/2013, 14/10/2014; 12/02/2015, 10/11/2015, 18/02/2016), and Article 236 of the Criminal Procedure Code of Ukraine was amended four times (by the laws of Ukraine dated 13/05/2015, 10/11/2015, 03/10/2017, 16/11/2017). Besides, some articles of the Criminal Procedure Code of Ukraine were amended repeatedly within a relatively short period (for example, Articles 170, 174 were amended, in particular, by the laws of Ukraine dated 18/04/2013 and 23/05/2013, and Article 303, in particular, by the laws of Ukraine dated 03/10/2017 and 16/11/2017). Some provisions of the Criminal Procedure Code of Ukraine, which were amended, were repealed after some time again.

For example, the wording of part 2 of Article 132, item one of part 1 of Article 184, and part 2 of Article 234 of the Criminal Procedure Code of Ukraine was first amended by the Law of Ukraine dated 03/10/2017, however, the Law of Ukraine dated 22/03/2018 on Amendments to the Criminal Procedure Code of Ukraine Regarding the Clarification of Certain Provisions restored the original wording of the relevant provisions due to the fact that amendments made by the law of Ukraine dated 03/10/2017 "...considerably complicated the work of the pre-trial investigation bodies in terms of a prompt, complete and impartial investigation" [22].

Some laws of Ukraine, amending, in particular, the articles of the Criminal Procedure Code of Ukraine, were subsequently repealed by the other laws of Ukraine (for example, the law of Ukraine dated 28/01/2014 was repealed by the law of Ukraine dated January 16, 2014 on Amendments to the Criminal Procedural Code of Ukraine Regarding the Criminal Proceedings in Absentia, the law of Ukraine dated January 16, 2014 on Amendments to the Law of Ukraine on the Judicial System and Status of Judges, as well as the procedural laws regarding additional measures to protect the safety of citizens) and certain provisions of the Criminal Procedure Code of Ukraine (including those, which were amended), were recognized unconstitutional (for example, the law of Ukraine dated 21/12/2016 supplemented Article 216 of the Criminal Procedure Code of Ukraine with part six, which later on was recognized as the one not corresponding to the Constitution of Ukraine (unconstitutional) by judgment № 3-p of the Constitutional Court of Ukraine dated April 24, 2018 [23].

Undoubtedly, this situation could not help reflecting on the criminal procedural law. As rightly asserted by O.A. Leiba, spontaneous situational rule-making dynamics of the criminal procedural legislation of recent years has led to an aggravation of the regulatory content challenges, which had been "painful" for law enforcement during five years, are still unresolved, create the new problems and aggravate the inconsistencies of individual structural elements of the criminal procedural legislation or form a mutual confrontation between some regulations; cause errors when establishing structural links with the use of blanket and reference regulations; cause violations of the laws of logic when developing the terminology and conceptual-categorical apparatus, etc. [24, p. 38].

Certainly, the current Criminal Procedure Code of Ukraine is a subject of numerous complaints. It contains contradictions and gaps, and some regulations allow an ambiguous and sometimes opposite interpretation. Many problems and difficulties are faced by practitioners applying those rules of the Criminal Procedure Code of Ukraine, the wording of which does not comply with the legal technique. Further, it should be emphasized that the reform of the criminal process cannot be carried out in a radical way, let alone stay ahead and determine amendments to the substantive law or determine the competences and the procedure of interaction between government agencies and officials, a system of which is not aligned properly yet.

As the embodiment of many social and legal developments in the field of criminal justice, both domestic and foreign, the Criminal Procedure Code of Ukraine sometimes added ideological tent to these legal categories. A striking example of this is definition of the criminal proceeding tasks (Article 2 of the Criminal Procedure Code of Ukraine). Without questioning the fundamental importance of the constitutional provisions on the priority of human rights and freedoms, as well as their safeguards, we can't help pointing out that the criminal process performs a security and protective functions exclusively in conjunction and within the proceeding, the subject of which is a socially dangerous act.

The criminal proceeding is primarily a process of establishing the presence or absence of a criminal offense in the act, availability of a criminal offense in the act of a specific person, a proof of its guilt (or innocence) in commitment of a criminal offense and so on. In this context and in connection with this, the criminal proceeding 
is a means of protecting a person, society and state from criminal offenses, and the appropriate regulation and implementation of criminal procedural activities safeguard the protection of rights, freedoms and legitimate interests of participants in the criminal proceeding.

Therefore, the need to protect the individual, society and state from criminal offenses determines the duty of the prosecutor or investigator to begin a pre-trial investigation in each case of a direct detection of criminal offense, or upon receipt of a report (notice) on commitment of a criminal offense. In this case, the protection of rights, freedoms and legitimate interests of participants in the criminal proceedings are rather a prerequisite, a means to conduct a lawful and impartial investigation and trial. Therefore, the criminal proceedings in any form, and in any country in the world is due, above all, to existence of a crime, and therefore the protection of the individual, society and state from criminal offenses is a common purpose rather than a specific task of the criminal proceeding, the task which has to be provided with adequate implementation means. Similarly, the protection of rights, freedoms and legitimate interests of participants in the criminal proceeding (i.e. protection of private interests) cannot be the driving force behind, the bases and, most importantly, the end result for the mostly public criminal procedural activities.

Protection of the rights, freedoms and legitimate interests of participants in the criminal proceeding is the regime and condition of the criminal justice implementation, in which the results are legitimate, appropriate and will ensure the achievement of the main goal, i.e. implementation of the criminal liability and remedy of the public relations damaged by a criminal offense. The rights, freedoms and legitimate interests of the participants in the criminal proceeding are protected within the initiated criminal procedural activity and continued throughout the period of its implementation, i.e. does not appear as the final result of the criminal proceedings, but rather is a prerequisite, the basis for its implementation.

The conditions reflect the features of the legal means by which the set tasks are performed and the goal is achieved [25, p. 126-127]. The conceptual drawbacks include the uncertainty of the principle of the rule of law and the absence of the related requirement on impartiality and competence of officials. Part 1 of Article 8 of the Criminal Procedure Code of Ukraine actually reflects the relevant constitutional provision (Article 3 of the Constitution of Ukraine), but as we know, it is not the Constitution and the laws which provide the rights to the people, but rather the people embody their rights through constitutional and other laws.

This means that the rule of law is not in the rule of the Constitution over the other laws in the state, the international treaty of Ukraine over national legislation, etc. (this is a part of the legality principle content), but in the understanding that human rights and freedoms are the foundation, the source, and not the result of the state law. The system of the criminal proceeding principles established by Article 7 of the Criminal Procedure Code of Ukraine, the principle of the rule of law is placed by the legislator in the first place, and therefore it operates as the so-called "principle of principles", the basis for the formulation and legislative consolidation of all other principles of the criminal proceeding. However, despite such fundamental importance of the rule of law, its wording as enshrined in Part 1 of Article 8 of the Criminal Procedure Code of Ukraine, as already mentioned, actually reproduces the relevant constitutional provisions, not giving answers to the questions about the content of this principle in the criminal proceeding. Still, the peculiarities of the criminal procedural activities, the presence of a significant number of the means of public law enforcement in its arsenal shifts the rule of law to the level of philosophy of the criminal proceeding, meaning philosophy not in the academic sense, but in practice.

Each operative officer, investigator, prosecutor, defender, investigating judge, or arbitrator should treat each criminal proceeding from this position. Enshrining the principle of the rule of law in the system of criminal proceeding principles, the legislator apparently pursued a different purpose than just duplicating the relevant constitutional provisions in the text of the Criminal Procedure Code of Ukraine. We hope that the legislator thereby tried to draw attention to the fact that a man as the highest social value, the inviolability of its rights and freedoms are of particular importance in the criminal proceeding, where the principle of legality and need to observe the procedural forms are the most important safeguards of human rights, and discretion limits of officials in positions of authority are clearly defined in the criminal procedural law.

Apparently, the developers of the current Criminal Procedure Code of Ukraine intended to indicate to the law enforcement entities that the criminal proceeding stipulated the need and the possibility of transcending behind the formal legitimacy (because it is interpreted as the ratio of the principle of legality and rule of law established for the domestic law). Otherwise, the rule of law loses its independent meaning and value, and any state in which the requirements of the law, especially those far from strengthening and ensuring the human rights and freedoms, are strictly followed, can be called legal [26, p. 383]. Currently, the issue of quality of the criminal procedural law, and the effectiveness of its provisions increasingly become the subject of research by the scientists, professional discussion meetings, conferences, seminars, round tables, and conferences at various levels, declaring the need to improve the criminal procedural law and formulating numerous proposals in this regard.

However, despite the fact that, on the one hand, currently, the law-making work of our MPs, aimed at the much-desired improvement of the current Criminal Procedure Code of Ukraine is still active, on the other, unfortunately, not all of the bills proposed for consideration, and even the laws adopted by the Verkhovna Rada of Ukraine and currently effective indeed contribute to achieving the declared objective; there are increasingly new grounds for a critical analysis of another improvement (attempts to improve) the criminal procedural law, both in terms of compliance with the rules of legislative technique, and in view of the effectiveness of the normative regulation of the criminal procedural activities, taking into account the legal and organizational aspects of its implementation.

Conclusions. The analysis of only some of the array of proposed bills in recent years, the purpose of which is declared as the effective implementation of overall objectives of the criminal proceeding, protection of rights, freedoms and legal interests of its members, etc. unfortunately, demonstrates a sad tendency towards the desire to change the law enforcement practice for the better, including in terms of human rights, only by means of legislative activity, not taking into account systemic methodological, legal and organizational problems.

The reasons for this situation are seen in the absence of adequate scientific justification of relevant amendments (or ignoring the available scientific heritage), the inconsistency in theoretical and methodological understanding of the relevant categories, a lack 
of systematic approach to specific areas of reform, taking into account not only the purely legal and procedural, but also organizational aspects.

However, as is known the objective situation and processes cannot be changed by rewriting laws only, without the proper methodological background, a system of administrative, managerial, and organizational measures, capable of providing for a systemic, consistent and effective implementation of the declared changes in law enforcement. Only such an approach will ensure the protection of human rights as the basis of civil society in both law and law enforcement.

\section{References:}

1. Фукуяма Ф. Доверие: социальные добродетели и путь к процветанию; пер. с англ. М. : ООО «Издательство АСТ»: ЗАО НПП «Ермак», 2004. $730 \mathrm{c}$.

2. Рішення Конституційного Суду України у справі за конституційним поданням Президента України щодо відповідності Конституції України (конституційності) підпункту 13 пункту 4 розділу I Закону України «Про внесення змін до деяких законів України щодо зменшення впливу світової фінансової кризи на сферу зайнятості населення» (справа про допомогу по безробіттю звільненим за угодою сторін) від 28 квітня 2009 року № 9-рп/2009. Офіційний вісник Украӥни. 2009. № 35. Ст. 1210.

3. Акімова Л.М. Аспекти реалізації засад антикорупційної політики. Реалізаиія державної антикорупиійної політики в міжнародному вимірі : матеріали III Міжнародної науково-практичної конференції (Київ, 7 грудня 2018 року). Ч. 2. Київ, 2018. С. 19-22.

4. Гоббс Т. Сочинения : В 2 т. Т. 2. М. : «Мысль», 1991.736 с.

5. Конвенція ООН проти корупції (прийнята 31 жовтня 2003 р.; ратифікована Україною 18 жовтня 2006 р.); офіційний переклад. Верховна Рада України / Законодавство Украӥни: [веб-сайт]. URL: https://zakon.rada.gov.ua/laws/show/995_c16.

6. Антикорупційна політика та запобігання корупції в публічному управлінні / І.С. Бондар, В.Г. Горник, С.О. Кравченко, В.В. Кравченко: навчальний посібник. Київ : «Ліра-К», 2016. 192 с.

7. Кохан Г.В. Явище політичної корупції: теоретико-методологічний аналіз : монографія. Київ : НІСД, 2013. 232 c.

8. Біленчук П.Д. Корупція як загроза національній безпеці України. Реалізація державної антикорупиійної політики в міжнародному вимірі: матеріали III Міжнародної науково-практичної конференції (Київ, 7 грудня 2018 року). Ч. 2. Київ, 2018. С. 31-33.

9. Четвертий раунд оцінювання. Запобігання корупції серед народних депутатів, суддів та прокурорів: Звіт за результатами оцінки. Україна (ухвалено на 76-му пленарному засіданні GRECO, Страсбург, 19-23 червня 2017 року) // Національне агентство 3 питань запобігання корупиії: [офіційний веб-сайт]. URL: https://nazk.gov.ua/sites/default/files/docs/2017/міжнародні\%20програми/GrecoEval4Rep(2016)9-P3-en-Ukraine_ukr.pdf.

10. Рівень довіри до суспільних інститутів та електоральні орієнтації громадян України // Центр Разумкова / Дослідження / Соціологічні дослідження: [сайт]. URL: http://razumkov.org.ua/napriamky/ sotsiologichni-doslidzhennia.

11. Українці не довіряють судам: результати нового опитування / Судебно-юридическая газета в Украине: [сайт]. URL: https://sud.ua/ru/news/ukraine/135851-ukrayintsi-ne-doviryayutsudam-rezultati-novogo-opituvannya.

12. Ставлення громадян до реформ в Україні // Центр Разумкова / Дослідження / Соціологічні дослідження: [сайт]. URL: http://razumkov.org.ua/napriamky/sotsiologichni-doslidzhennia.

13. Ставлення громадян України до судової системи // Центр Разумкова / Дослідження / Соціологічні дослідження: [сайт]. URL: http://razumkov.org.ua/napriamky/sotsiologichni-doslidzhennia.
14. Барандич С. Правозастосування в сучасному вимірі юридичної науки. Науковий часопис Наиіональної академії прокуратури Украӥни. 2014. Вип. 4. С. 1-7.

15. Концепція судово-правової реформи в Україні : схвалена постановою Верховної Ради України від 28 квітня 1992 р. Відомості Верховної Ради України. 1992. № 30. Ст. 426.

16. Концепція реформування кримінальної юстиції України: затв. Указом Президента України від 8 квітня 2008 р. № 311. Офіиійний вісник України. 2008. № 27. Ст. 838.

17. Кримінальний процесуальний кодекс України: Закон України від 13 квітня 2012 р. Офіиійний вісник України. 2012. № 37. Ст. 1370.

18. Стратегія реформування судоустрою, судочинства та суміжних правових інститутів на 2015-2020 роки: схвалена Указом Президента України від 20 травня 2015 р. № 276. Офіційний вісник Украӥни. 2015. № 41. Ст. 1267.

19. Про внесення змін до Кримінального процесуального кодексу України щодо порядку тимчасового вилучення майна та проведення обшуку : Закон України від 13 травня 2015 р. Відомості Верховної Ради України. 2015. № 28. Ст. 251.

20. Про внесення змін до Кримінального та Кримінального процесуального кодексів України стосовно виконання Плану дій щодо лібералізації Європейським Союзом візового режиму для України: Закон України від 18 квітня 2013 р. Відомості Верховної Ради України. 2014. № 11. Ст. 131.

21. Про внесення змін до Господарського процесуального кодексу України, Цивільного процесуального кодексу України, Кодексу адміністративного судочинства України та інших законодавчих актів: Закон України від 3 жовтня 2017 р. Відомості Верховної Ради України. 2017. № 48. Ст. 436.

22. Пояснювальна записка до проекту Закону України «Про внесення змін до Кримінального процесуального кодексу України щодо уточнення окремих положень» // Верховна Рада України: [офіційний веб-портал]. URL: http://w1.c1.rada.gov.ua/pls/zweb2/webproc4_1?pf3511=63658.

23. Рішення Конституційного Суду України у справі за конституційним поданням Уповноваженого Верховної Ради України з прав людини щодо відповідності Конституції України (конституційності) частини шостої статті 216 Кримінального процесуального кодексу України від 24 квітня 2018 року № 3-р/2018. Офіщійний вісник України. 2018. № 41. Ст. 1459.

24. Лейба О.А. Дефекти кримінального процесуального законодавства та засоби їх подолання : монографія. Харків : «Юрайт», 2018. $216 \mathrm{c}$.

25. Рожнова В.В. Сучасна концепція кримінального процесу та ії відображення у системі завдань кримінального провадження. Проблеми правознавства та правоохоронної діяльності. 2012. № 4. C. 122-128.

26. Рожнова В.В. Верховенство права у системі засад кримінального провадження. Університетські наукові записки. Хмельницький. 2012. № 4. C. 381-387.

Рожнова В. В., Савицький Д. О. Про ефективне правозастосування, що засноване на довірі (на прикладі кримінального процесуального законодавства України)

Анотація. У статті проаналізовано окремі питання формування та сучасного стану суспільної довіри у відносинах держави та громадянського суспільства в Україні. Досліджено сучасний стан законотворчості й правозастосування, зокрема у сфері кримінального провадження, крізь призму функціональної здатності кримінального процесу, що заснована на довірі.

Встановлено, що система протидії корупції, насамперед, повинна бути спрямована на усунення умов для корупції, а не на боротьбу із ії наслідками, та охоплювати 
не лише заходи соціально-економічного, політичного, організаційного, правового характеру, а й технології формування суспільної свідомості.

Впровадження електронного урядування визнано одним із найбільш оптимальних, ефективних і перспективних напрямів розвитку вітчизняного державного управління у системі протидії корупції та підвищення рівня суспільної довіри.

Визначено, що і закон, і правозастосування, будучи тісно взаємопов'язаними, мають об'єктивні передумови, зумовлені тими процесами, що відбуваються в суспільстві на певному етапі його розвитку. Критерієм рівня співвідношення та взаємовпливу закону і правозастосування у сфері кримінального провадження визнано їх взаємну функціональну спроможність забезпечити виконання його загальних завдань. Саме це і визнається адекватною відповіддю на очікування, які покладаються суспільством на систему кримінальної юстиції.
Наразі констатується тенденція до прагнення змінити правозастосовну практику на краще лише засобами законотворчої діяльності без урахування системних проблем методологічного, правового та організаційного характеру. Однак вплинути на об'єктивний стан речей і процесів неможливо лише переписуванням законів, без належного методологічного підгрунтя, системи адміністративно-управлінських, організаційних заходів. Лише такий підхід здатний забезпечити системне, послідовне та ефективне впровадження задекларованих змін у правозастосування.

Ключові слова: суспільна довіра, ефективне правозастосування, функціональна здатність кримінального провадження, система протидії корупції, сучасні тенденції законотворчості у сфері кримінального провадження, реформування кримінального процесуального законодавства України. 